\title{
frontiers
}

FOR YOUNG MINDS

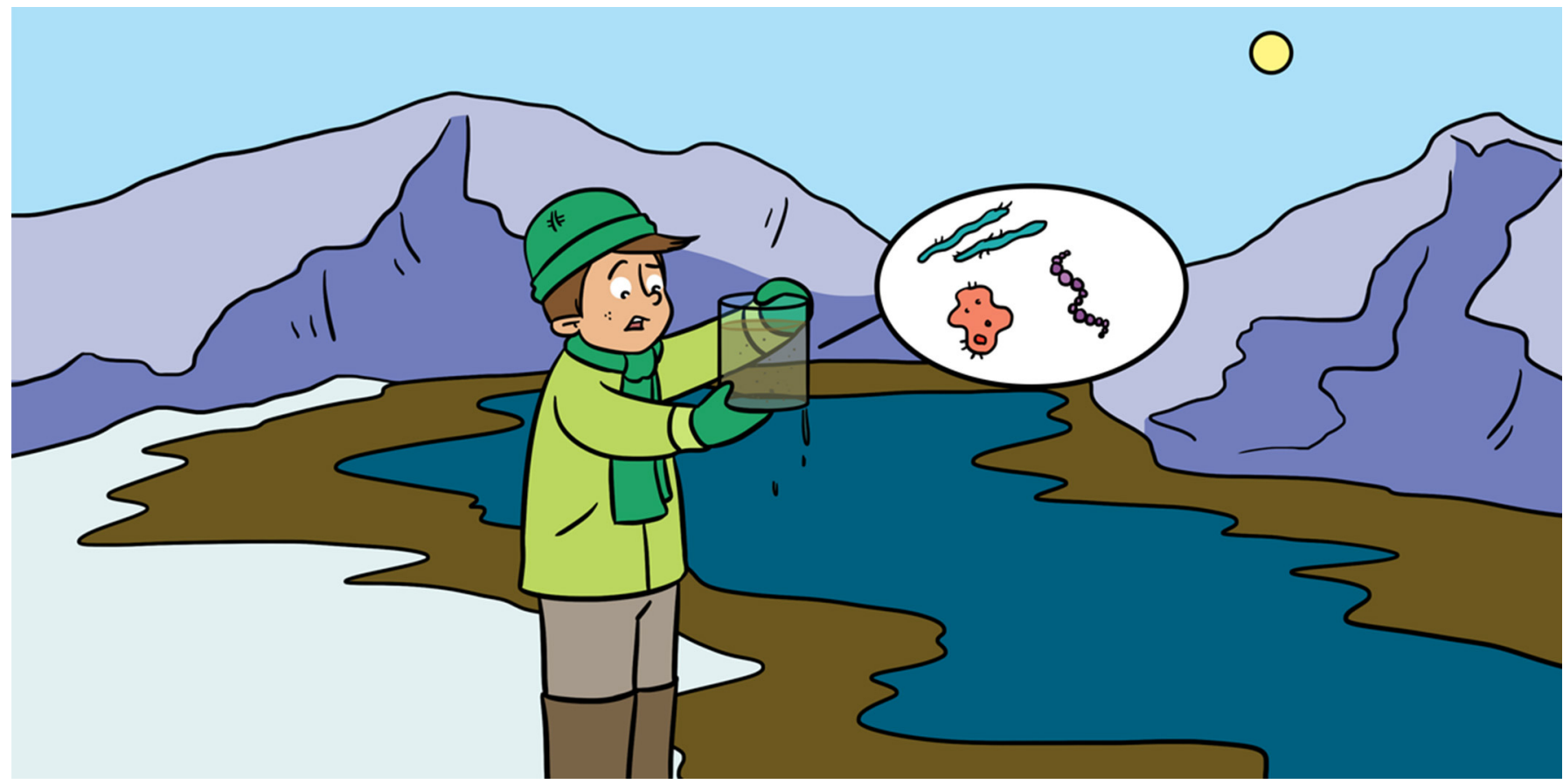

\section{HOW DO DARK STREAMS OF ARCTIC GLACIAL MELTWATER AFFECT PLANKTON?}

\section{Marlena Szeligowska ${ }^{1 *}$, Déborah Benkort ${ }^{2}$, Emilia Trudnowska ${ }^{1}$ and Katarzyna Btachowiak-Samołyk ${ }^{1}$}

Pelagic Biocenosis Functioning Laboratory, Marine Ecology Department, Institute of Oceanology, Polish Academy of Sciences, Sopot, Poland

2Matter Transport and Ecosystem Dynamics, Institute of Coastal Systems-Analysis and Modeling, Helmholtz-Zentrum Hereon, Geesthacht, Germany

YOUNG REVIEWERS:

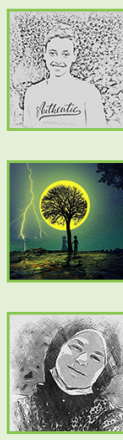

In the last decades, the temperatures of Earth's atmosphere and its oceans have increased significantly. Warming strongly affects the Arctic, where we can observe fast glacial melt during the summer. Meltwater brings debris from the land into the coastal ocean, creating zones with brown water. This seawater darkening can affect the living conditions of marine organisms and possibly threaten marine life in the future. To address this issue, we studied the particles that make the seawater dark and the effect that seawater darkening has on the tiny plants and animals in the coastal waters of the European Arctic. Open, clear waters were greenish and full of life, while in muddy brown zones, we observed intensive "snowstorms" of particles. Our study taught us about how marine organisms interact with these particles. Based on our observations, we can design computer models to help us predict the fate of the coastal waters in a future, warmer Arctic. 
Figure 1

Seasonal changes in the Svalbard archipelago in the European Arctic. (A) Satellite images show that, in March, sea ice is at its maximum extent. (B) July is the peak of the melting season and we can see the presence of "brown zones." (C) The area shown in $A$ and $B$ is inside the black box. The red arrow shows the flow of warm water from the Atlantic [lmage credits: $(\mathbf{A}, \mathbf{B})$ https://glovis.usgs.gov/ app; (C) generated using ArcGIS Pro 2.5].

\section{PHYTOPLANKTON}

Marine organisms that live in the surface waters and use photosynthesis to grow. They are food for zooplankton.

\section{PHOTOSYNTHESIS}

The process of creating energy (in the form of sugar) from sunlight and carbon dioxide. Photosynthesis is used by plants, algae, and certain bacteria.

\section{ZOOPLANKTON}

Small organisms that drift with water currents. They are food for fish, seabirds, and whales.

\section{MARINE}

ECOSYSTEM

Communities of bacteria, plants, and animals living and interacting with each other in an aquatic environment such as sea or the ocean.
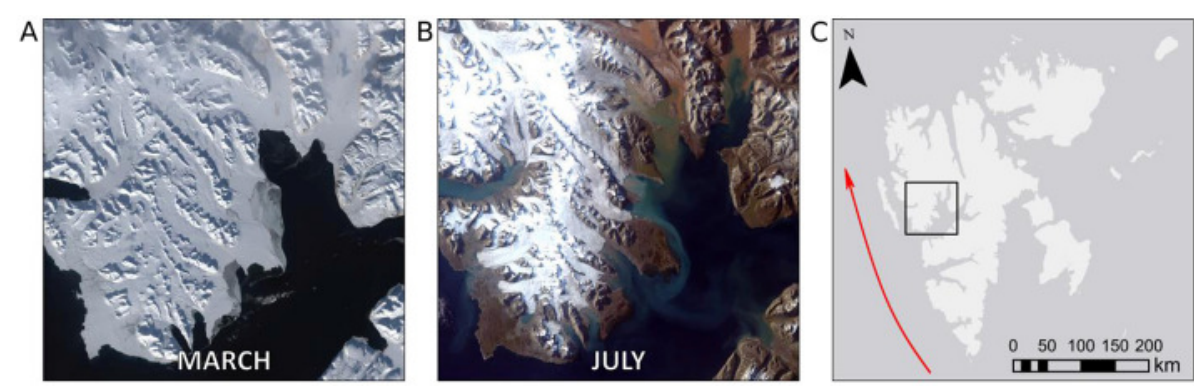

Figure 1

\section{THE NATURAL CYCLE}

The Arctic glaciers and ice caps experience seasonal cycles of melting and freezing. The polar night is a period of complete darkness when the sea and land are covered by snow and ice (Figure 1A). When the first rays of polar day reach the area, the ice on both land and sea melts and shrinks, and rivers start to deliver glacial meltwater to the coastal zones. It is spring-the most productive time of the year. Tiny marine plants, called phytoplankton, grow and multiply quickly, using sunlight and nutrients in the water to produce food via photosynthesis. Zooplankton, which are small animals carried along by water currents, feed primarily on phytoplankton. In the Arctic, zooplankton are most numerous during summer, which is also the main melting season (Figure 1B). During the summer, zooplankton must accumulate fat to survive hibernation over the winter. When polar night comes, there is less sunlight and temperatures decrease quickly. Ice and snow accumulate on land and water. Rivers become frozen and their run-off into the ocean ceases.

The natural seasonal cycle of the Arctic is being altered by global warming. Ice and snow are starting to melt more quickly and earlier in the season, and less ice is formed in winter. But warming does not only affect physical structures such as glaciers; it is also responsible for many changes in the Arctic's marine ecosystem.

\section{WHAT DOES A WARMING ARCTIC MEAN FOR COASTAL WATERS?}

In polar regions, coastal waters are undergoing remarkable changes. To study them, every summer we go to the Svalbard archipelago in the Arctic. It is a perfect place to study the effects of global warming due to the observed increased flow of warm oceanic water from the Atlantic (Figure 1C, red arrow) and accelerated glacial melting. Freshwater from melting glaciers flows to the sea and brings mud from the land. The muddy water causes seawater darkening, since the mud particles prevent light from penetrating the water. In satellite images, we can see that the dark waters spread further and further 
Figure 2

(A) Muddy and (B) clear waters during the Arctic summer. The left edges show the underwater pictures (Photo credits: Kajetan Deja)

\section{SEAWATER}

\section{DARKENING}

Worsening underwater light conditions due to the presence of many particles, which prevent light from penetrating the water.

\section{TURBIDITY}

The measure of relative clarity of a water.

\section{MARINE SNOW}

Macroscopic aggregates of detritus, living organisms, and inorganic particles falling from the upper layers of the water column to the seafloor.
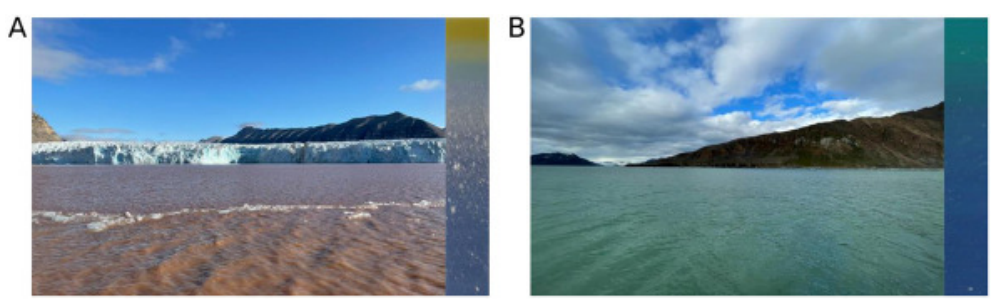

Figure 2

every year. Light influences the life cycles and growth of all marine organisms. If changes in underwater light during the Arctic summer become severe, phytoplankton will not be able to photosynthesize, so they will become less abundant. A decrease in phytoplankton creates unfavorable food conditions for zooplankton and decreases their growth, which can then negatively affect fish, polar bears, seals, and seabirds [1].

\section{CHALLENGE ACCEPTED}

Although seawater darkening caused by glacial meltwater can have serious effects on the marine ecosystem, it has received less attention than sea ice loss $[2,3]$. Since we believe seawater darkening is just as important as other effects of global warming, we took up the challenge of studying it! We geared up with a lot of equipment and went to the Arctic to catch the muddiest water coming from land (Figure 2A). We used a digital camera to snoop on marine organisms in their natural environment (Figure 2, edges). We also used special devices to measure underwater light distribution, counted particles, and examined plankton. We studied areas with clear, open waters outside the "brown zones," as a comparison (Figure 2B). We determined the levels of turbidity in each of the areas we studied. Turbidity is a measure of how dirty the water is.

\section{UNDERWATER SNOW}

In the glacial bays, turbidity was high, which means that the water was dirty. It had a milky brownish color due to the presence of small particles delivered from the land (Figure 3A, Table 1). These particles tended to stick together creating "flakes," which gave us the impression of an intensive underwater snowstorm. In contrast, turbidity was extremely low in clear waters, which had a green color due to the presence of pigments in the phytoplankton (Figure 3B). Marine snow was less abundant in clear waters and it was composed of flocks of dead phytoplankton, zooplankton, and feces-signs that organisms are living there. 
Figure 3

(A) Mineral particles from the land give muddy surface water a milky brown color. Particles stick together and look like

underwater snow. Inside the "brown zones," phytoplankton have less light for photosynthesis, so there are fewer phytoplankton for the zooplankton that eat them. Ultimately, jellies that eat small zooplankton starve as well. (B) Clear water is greenish due to the phytoplankton pigments. Clear water is full of phytoplankton, which are eaten by zooplankton, which are then eaten by jellies

\section{Table 1}

Comparison of muddy and clear Arctic waters during the melting season.

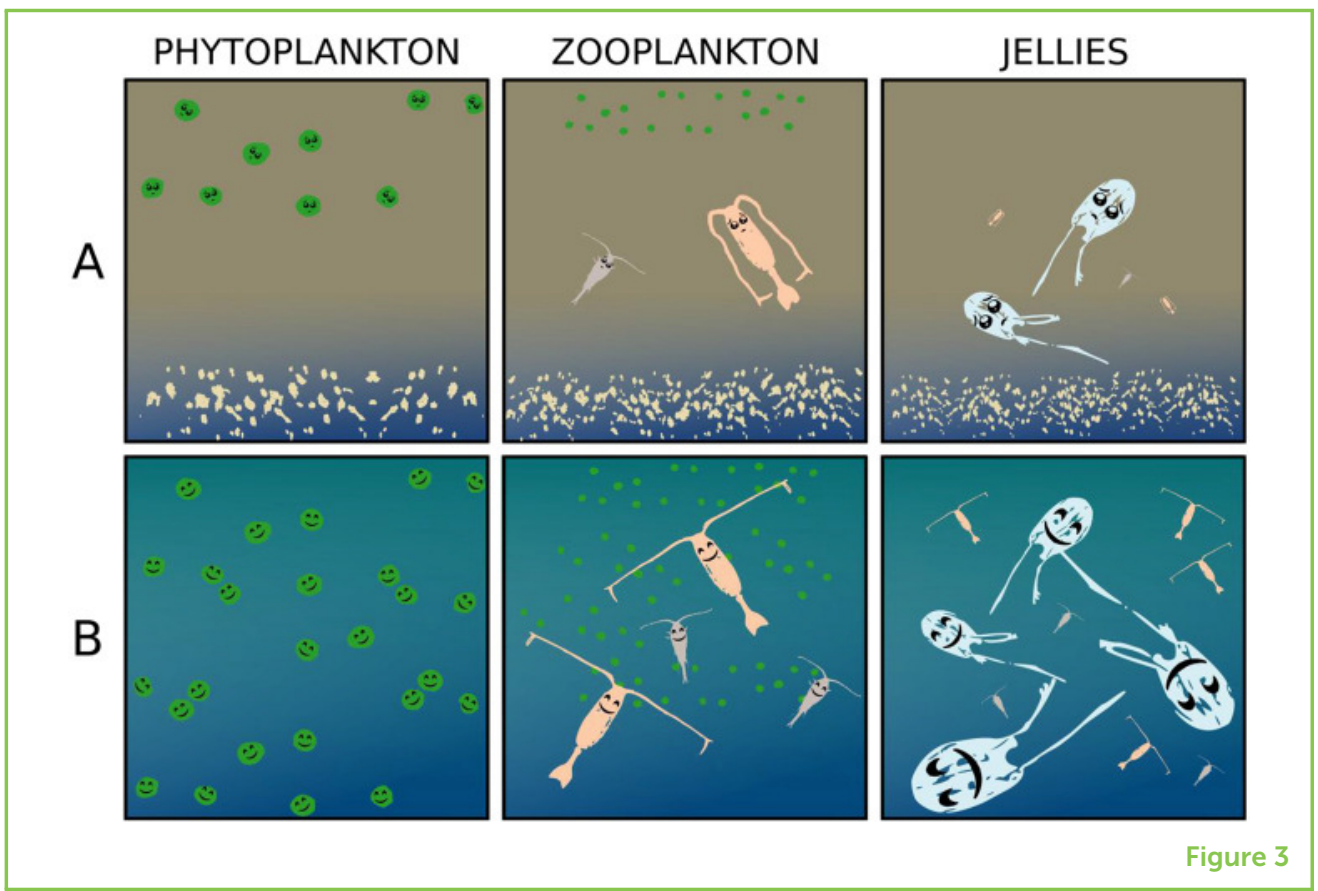

\begin{tabular}{lll}
\hline & Muddy & Clear \\
\hline Water color & Milky brown & Green \\
Turbidity & High & Low \\
Marine snow & High & Low \\
Green pigment & Low & High \\
Phytoplankton & Low & High \\
Zooplankton & Low & High \\
Jellies & Low & High \\
\hline
\end{tabular}

Table 1

Inside the "brown zones," phytoplankton was only present close to the surface, where it could catch every ray of light. Zooplankton was also less abundant and was the least abundant in shallow, enclosed areas where water exchange was limited. However, some zooplankton species were affected less than others, because they can feed on marine snow. One type of zooplankton, called gelatinous zooplankton (or jellies), turned out to be a good indicator of darkening conditions. Although they are predators that use their sense of touch and do not need light to catch their prey, jellies were scarce in the murky waters, probably because there was less food available close to glaciers-they feed on small zooplankton, or that the marine snow particles could clog their sticky tentacles.

\section{FROM OBSERVATIONS TO PREDICTIONS}

We obtained a lot of information from our measurements, but our data could not tell us everything we wanted to know about how plankton and particles interact in such worsen conditions during Arctic summer. 


\section{COMPUTER MODEL}

Set of mathematical equations that describe the behavior of natural systems and that are used to simulate what might or what did happen.
To learn more, we created computer models, which are programs that use mathematical equations to help scientists better understand their observations and make predictions about the future. To represent the physical conditions (temperature, salinity, currents, etc.) in our study region, we used a model called GOTM. To represent the living matter (phytoplankton, zooplankton, etc.), we used a model called ECOSMO. These two models were linked together, which allowed us to create a virtual world representing our study site. Our model contained general knowledge of who-eats-whom in the Arctic marine ecosystem.

How does the model work? For every day of the year, we input the data that are measured or modeled, including water temperature, salinity (saltiness), and the amount of mud delivered from land. The model uses this input to calculate how the organisms eat and grow. The output from the model is the weight of each group of organisms, which tells us how abundant each group is. The model is structured to give us the weight of phytoplankton, zooplankton, and the larvae of organisms living on the ocean bottom. So far, the model results and our field data show similar trends for all these plankton groups, which is good news! It means that the first step of our model development is working well.

The next step is to use our simple model to predict how gradual warming will affect various plankton groups. To do that, we need to run simulations with possible future environmental data, to predict what might happen to each group of organisms. We can test many things that have not yet happened in the real world; for e.g., we can use our model to predict what will happen to our marine ecosystem if the air and ocean temperatures continue to rise as predicted by climate models. Our model predicts that higher temperatures will result in more mud and marine snow in our future coastal waters. We can continue to improve and modify our model all the time, based on the real-world data we collect. At some point, we hope that this model will become an even more complex and powerful tool to help researchers make predictions upon which we can base actions to protect Arctic ecosystems.

\section{SUMMARY}

The Arctic experiences effects of climate change that are more pronounced than anywhere else on Earth. Its future is unclear. There may be a moment called a tipping point, when warming will become irreversible and begin to spread like a wildfire. We certainly will not be able to stop all the changes that will happen in the Arctic ecosystem, but we can observe them, to prepare us for the future. By studying what is happening in darkening waters, we noticed that dark water has a negative effect on plankton, especially on jellies. Changes in the populations of small planktonic organisms can travel up the food chain and possibly have negative effects even on top predators, 
altering the entire Arctic ecosystem. We are continuing to design virtual experiments that incorporate the essential components of the Arctic coastal waters. Using these computer models, we hope to better understand the aftermath of seawater darkening caused by glacial melting. More research is needed because, at this point, we still do not know how strong the impact of seawater darkening on plankton-and possibly the whole Arctic food web-will be in the future.

\section{FUNDING}

This study was funded by Polish National Science Centre project (NCN, CoastDark2018/29/B/NZ8/02463), Polish Ministry of Science and Education grant (AREX Project 3547/Norway/2016/2), DAAD short-term research grant 2020 (57507441), Changing Arctic Ocean project MiMeMo (NE/R012679/1) jointly funded by the UKRI Natural Environment Research Council (NERC), and the German Federal Ministry of Education and Research (BMBF/03F0801A). This survey was additionally supported by the statutory activity of the Institute of Oceanology Polish Academy of Sciences (IO PAN).

\section{ORIGINAL SOURCE ARTICLE}

Szeligowska, M., Trudnowska, E., Boehnke, R., Dabrowska, A. M., Dragańska-Deja, K., Deja, K., et al. The interplay between plankton and particles in the Isfjorden waters influenced by marine-and land-terminating glaciers. Sci. Total Environ. (2021) 780:146491. doi: 10.1016/j.scitotenv.2021.146491

\section{REFERENCES}

1. Lydersen, C., Assmy, P., Falk-Petersen, S., Kohler, J., Kovacs, K. M., Reigstad, M., et al. 2014. The importance of tidewater glaciers for marine mammals and seabirds in Svalbard, Norway. J. Mar. Syst. 129:452-71. doi: 10.1016/j.jmarsys.2013.09.006

2. Heath, M., Benkort, D., Brierley, A., Daewel, U., Hofmeister, R., Laverick, J., et al. 2020. How is climate change affecting marine life in the arctic? Front. Young Minds. 8:103. doi: 10.3389/frym.2020.00103

3. Kohlbach, D., and Lange, B. 2020. How melting arctic sea ice can lead to starving polar bears. Front. Young Minds. 8:111. doi: 10.3389/frym.2020.00111

SUBMITTED: 22 July 2021; ACCEPTED: 11 January 2022;

PUBLISHED ONLINE: 08 February 2022.

EDITOR: Suhas Kumar, Hewlett-Packard, United States

SCIENCE MENTOR: Nordin Ben Seddik 

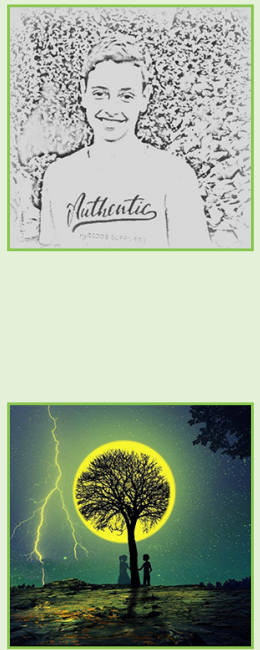

CITATION: Szeligowska M, Benkort D, Trudnowska E and Błachowiak-Samołyk K (2022) How Do Dark Streams of Arctic Glacial Meltwater Affect Plankton? Front. Young Minds 10:745930. doi: 10.3389/frym.2022.745930

CONFLICT OF INTEREST: The authors declare that the research was conducted in the absence of any commercial or financial relationships that could be construed as a potential conflict of interest.

COPYRIGHT ( 2022 Szeligowska, Benkort, Trudnowska and Błachowiak-Samołyk. This is an open-access article distributed under the terms of the Creative Commons Attribution License (CC BY). The use, distribution or reproduction in other forums is permitted, provided the original author(s) and the copyright owner(s) are credited and that the original publication in this journal is cited, in accordance with accepted academic practice. No use, distribution or reproduction is permitted which does not comply with these terms.

\section{YOUNG REVIEWERS}

\section{HAYTAM, AGE: 13}

My name's Haytam, I am 13 years old. My academic level is the third preparatory. My favorite subjects are: maths, physics, science, and English. My hobbies are: swimming, drawing and reading. I practiced taekwondo for 2 years. I speak English and French fluently. I have previously participated in the arab reading challenge and I participated in the math Olympiad too. My dream is to become a doctor or a vet.

\section{HIBA, AGE: 15}

My name is Hiba, I am 15 years old, my academic level is the first year of high school, my favorite subjects are English, physics, and mathematics, my hobbies are scientific research and swimming. I did theater and ballet for a year and took part in the reading challenge in primary school. I speak French and English my dream is to become a scientific researcher or psychiatrist.

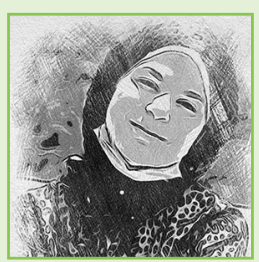

\section{RIM, AGE: 15}

In my free time, I read novels, watch series, and surf the net. My favorite subjects are physics and mathematics. I really like swimming and cycling. My dream is to carry out my own project because I am interested in business.

\section{AUTHORS}

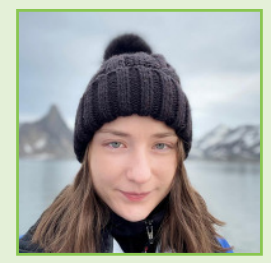

\section{MARLENA SZELIGOWSKA}

I am a Ph.D., student at the Institute of Oceanology Polish Academy of Sciences. I work on the CoastDark project, which is focused on the consequences of seawater darkening due to glacial meltwater discharge in the European Arctic. I combine and analyze huge datasets from observations to make predictions about the future. I am also a visiting student at Helmholtz-Zentrum Hereon, Germany, 


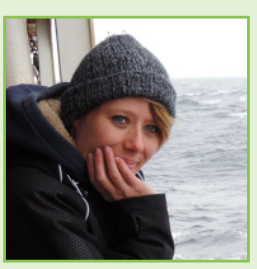

where I learn about modeling and design my virtual experiments for the Arctic coastal waters. *lena@iopan.pl

\section{DÉBORAH BENKORT}

I am a scientist at the Helmholtz-Zentrum Hereon, Germany, working on modeling the chemistry and plankton of the Arctic, on the MiMeMo-CAO project. In the ecosystem model, I implemented sea-ice biology and its interactions with the pelagic and benthic food web. I study the ecosystem's response to global warming, to identify long-term ecosystem dynamic changes. My Ph.D., research focused on zooplankton in the Gulf of St. Lawrence, on the Canadian east coast. I developed models to study their growth and reproduction.

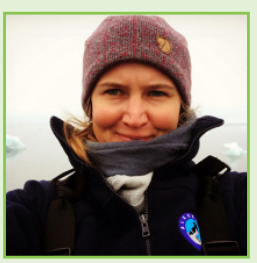

\section{EMILIA TRUDNOWSKA}

I am a post-doc at the Institute of Oceanology Polish Academy of Sciences in the Marine Ecology Department. I am an expert in Arctic zooplankton and I have experience using new technologies like laser counters and underwater cameras to study particles and how they affect plankton, the marine environment, and various ecological processes.

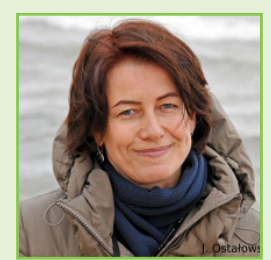

\section{KATARZYNA BŁACHOWIAK-SAMOŁYK}

I am a senior scientist at the Institute of Oceanology Polish Academy of Sciences, coordinating the CoastDark project. I am experienced in the marine ecology of zooplankton from polar regions and their relationship with planktivorous predators such as seabirds. Zooplankton ecology during the polar night is also something that fascinates me, just like planktonic ostracods. 